Check for updates

London

Cite this as: $B M J$ 2021;372:n726 http://dx.doi.org/10.1136/bmj.n726 Published: 16 March 2021

\section{Covid-19: Italy reimposes widespread lockdown as transmission rate rises again}

\author{
Michael Day
}

Italy has once again emerged as Europe's covid-19 hotspot, with half the country forced into the tightest tier of lockdown as virus transmission rates continue to rise and intensive care wards again buckle under the strain of new cases.

Rome's decision on 15 March to suspend use of the AstraZeneca vaccine, along with France, Germany, and Spain, has exacerbated the already difficult situation.

The Italian Medicines Agency (Aifa) announced the precautionary ban on using the vaccine after reports in Italy and elsewhere in Europe of people developing dangerous blood clots after receiving the jab. Aifa's announcement came just hours after it declared that the alarm over the jab's safety was "unjustified" and that "no causal links" had been shown between the vaccine and the blood clots.

Nicola Magrini, director general of Aifa, said that the decision had been taken to fall into line with other EU nations, ahead of a European Medicines Agency review due on Thursday 18 March.

Roberto Speranza, health minister, said on 16 March that Italy was right to suspend use of the AstraZeneca vaccine until the European Medicines Agency had confirmed its safety. Infectious disease experts are fearful, however, of the effects of this suspension in an already vaccine sceptic country.

Massimo Galli at Milan's Sacco Hospital told the Adnkronos news agency that he feared that the suspension would "do great damage by creating further uncertainties in people's minds.” Some Italian teachers have claimed that plans to prioritise their profession for immunisation amount to using them as vaccine guinea pigs.

In December The BMJ reported that an Italian doctors' association had warned or disciplined 10 medics for promoting anti-vaccination propaganda and that it was considering sanctions against three others accused of downplaying the gravity of covid-19. ${ }^{2}$

\section{Wasted doses}

Even before the setback to the AstraZeneca jab, limited vaccine supply and poor organisation were hampering Italy's efforts to immunise people. Just over 6.7 million doses of vaccine have been administered to date, compared with nearly 25 million doses in the UK. ${ }^{3}$

La Repubblica newspaper reported on 15 March that in the northern region of Lombardy, the area of Italy worst hit by covid-19, only a third of 726000 elderly people who were supposed to have been invited for vaccination had so far been contacted. Some reports have said that batches of vaccine are going to waste because health officials have not arranged for willing appointments.

In response, Italy's covid-19 emergency commissioner, Francesco Paolo Figliuolo, said that he would order regional authorities to prepare lists of "vaccination reserves"-people willing to come in at the last minute to have a jab, to "avoid the risk of wasting doses."

The need for action was underlined by news of government data showing that Italy's average covid-19 R reproduction number had risen to 1.16 from 17 February to 2 March. This was a significant rise on the R of 1.06 of the previous two week period's monitoring report compiled by experts from the health ministry, the Higher Health Institute, and regional officials. ${ }^{4}$ Their report said that the proportion of intensive care beds taken up by patients with covid-19 had passed the key threshold of 30\%, rising from $26 \%$ to $31 \%$.

As a result, most of Italy, including Rome and Milan, has this week gone into the strictest lockdown. All schools, colleges, and shops are closed again in nine regions and in the autonomous province of Trento, with restaurants selling only takeaway food. The rest of the country has been placed under a lesser, "orange" level lockdown.

1 European Medicines Agency. EMA's safety committee continues investigation of COVID-19 Vaccine AstraZeneca and thromboembolic events-further update. 15 Mar 2021. https://www.ema.europa.eu/en/news/emas-safety-committee-continues-investigation-covid19-vaccine-astrazeneca-thromboembolic-events.

2 Day M. Covid-19: Italian doctors are disciplined for anti-vaccination propaganda. BM/2020;371:m4962. doi: 10.1136/bmj.m4962 pmid: 33380409

3 Number of COVID-19 vaccine doses administered in Italy as of March 16, 2021, by region. Statista 2021 Mar 16. https://www.statista.com/statistics/1196406/number-of-covid-vaccine-doses-administered-in-italy-by-region/.

4 Health Ministry (Italy). Novel coronavirus. http://www.salute.govit/portale/nuovocoronavirus/archivioNotizieNuovoCoronavirus.jsp. (Available in Italian and English.)

This article is made freely available for use in accordance with BMJ's website terms and conditions for the duration of the covid-19 pandemic or until otherwise determined by BMJ. You may use, download and print the article for any lawful, non-commercial purpose (including text and data mining) provided that all copyright notices and trade marks are retained. volunteers to replace those who fail to turn up for 